\title{
INTENSITAS KERJA PADA AKTIVITAS NELAYAN PURSE SEINE DI KABUPATEN SIKKA
}

Intensity Work Activities Purse Seine Fishing In The District Sikka

Oleh:

Yohanes DBR Minggo ${ }^{1 *}$, Budhi Hascaryo Iskandar², Fis Purwangka²

${ }^{1}$ Mahasiswa Program Studi Teknologi Perikanan Laut

2Staf Pengajar Program Studi Teknologi Perikanan Laut

KKorespondensi: riksonminggo89@gmail.com

\begin{abstract}
ABSTRAK
Data kecelakaan nelayan di Kabupaten Sikka tahun 2014 hingga 2015 disebutkan telah terjadi 10 kasus kecelakaan. Nelayan di Kabupaten Sikka pada umumnya menggunakan alat tangkap purse seine. Pengoperasian alat tangkap purse seine dilakukan secara manual sehingga banyak membutuhkan tenaga dan pikiran yang berpengaruh pada tingkat kelelahan hingga berpotensi terjadinya kecelakaan. Tujuan dalam penelitian ini adalah untuk mengidentifikasi aktivitas dan melihat intensitas kerja nelayan yang dapat berpotensi menimbulkan kecelakaan pada saat melakukan pengoperasian alat tangkap purse seine. Metode yang digunakan adalah deskriptif numerik dengan analisis Hierarchical Task Analysis (HTA). Hasil penelitian menunjukan bahwa terdapat 10 tahapan aktivitas dengan jumlah aktivitas sebanyak 62 aktivitas dengan porsi tanggung jawab terbesar adalah kepala kerja. Rangking aktivitas tertinggi terdapat pada tahap ke 5, 8, dan 4 yakni hauling, unloading hasil tangkapan dan setting. Perlu adanya perhatian khusus pada ketiga tahapan tersebut agar proses penangkapan ikan bisa dilakukan dengan baik dan aman.
\end{abstract}

Kata kunci: hta, intensitas kerja, keselamatan kerja,purse seine, Sikka.

\section{ABSTRACT}

In last two years (2014-2015) there were 10 fishing accidents in Sikka Province. In Sikka Province, the fisherman mostly use purse seine. Purse seine is operated manually so that require force and high concentration that influence fatigue until become an accident. The aim of this research were to indentify activity and to see the work intensity from fisherman that potentially causing accidents when they opperating purse seine. The method that used in this study was numeric descriptive with Hierarchical Task Analysis (HTA). The result of this study showed there were 10 stages activities with 62 total activities that had the most portion of responsibility, it was owned by the chief. The highest activities contained in phase 5, 8 , and 4 (hauling, catch unloading, and setting). Special attention needs for that three stages, to make the fishing activity can be done properly and safely.

Keywords: HTA, Labor intensity, Safety work, Purse seine, Sikka. 


\section{PENDAHULUAN}

Salah satu upaya dalam melindungi, menjamin keselamatan, serta keamanan dankenyamanan kerja awak kapal perikanan di laut yang harus diperhatikan adalah faktor keselamatan operasional kapal perikanan di laut, terutama ketersediaan fasilitas keselamatan dan kesehatan di atas kapal. Menurut Thimotius (2015) dengan terciptanya keselamatan dan kesehatan kerja yang baik akan memberikan ketenangan serta kegairahan kerja.

Keselamatan kerja dalam kaitan dengan perikanan tangkap secara khusus memiliki tujuan yaitu untuk mencegah atau mengurangi kecelakaan serta akibatnya dalam kemungkinan terjadinya bahaya dan risikopada saat melakukan aktivitaspenangkapan, menurut data International Labour Organization (ILO), setiap tahun terjadi 1.1 juta kematian yang disebabkan karena penyakit dan kecelakaan dalam hubungan dengan pekerjaan, dimana sekitar 300.000 orang mengalami kematian dari 250 juta kecelakaan dan sisanya adalah kematian karena penyakit akibat hubungan pekerjaan di lingkungan kerja itu sendiri, Wibisono B (2013). Menurut Lincoln et al(2000) permasalahan yang berkaitan dengan keselamatan kerja nelayan di laut hingga mengakibatkan kecelakaan dikarenakan oleh salah satu elemen dari human factor, machines atau enviromental factor tersebut tidak berfungsi dengan baik, dari hasil kajian yang dikemukakan oleh FAO (2009) Penyebab utama kecelakaan di laut hingga menelan korban jiwa diakibatkan oleh kesalahan manusia (human error) dan menurut Handayani (2014) timbulnya kecelakaan di laut dikarenakan adanya pengabaian yang dilakukan oleh penyelenggara transportasi laut dan instansi-instansi terkait, serta perlengkapan keselamatan kerja di laut yang tidak memadai sehingga peluang risiko kecelakaan di laut cukup tinggi.

Menurut BASARNAS (2016) dalam kurung waktu dari tahun 2014 hingga 2015 di Kabupaten Sikka telah terjadi 10 kasus kecelakaan yang dimana kecelakaan tersebut diakibatkan oleh mati mesin sebanyak 50\%, badai 40\% dan karam sebanyak 10\% dengan jumlah korban pada tahun 2014 sebanyak 65 orang dan di tahun 2015 sebanyak 13 orang.

Penyebab Kecelakaan

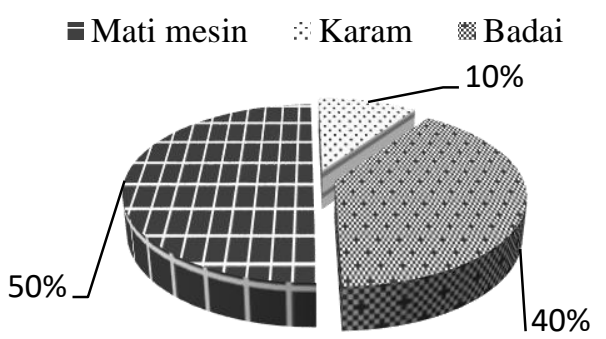

Jumlah korban kecelakaan

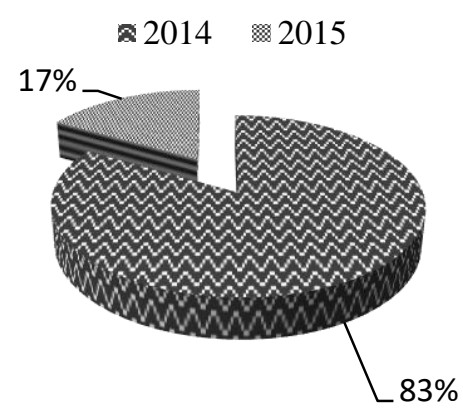

Sumber: Basarnas Nusa Tenggara Timur

Gambar 1 Jumlah dan penyebab kecelakaan di Kabupaten Sikka tahun 2016

Kabupaten Sikka merupakan salahsatu kabupaten yang masyarakatnya dominan bekerja sebagai sebagai nelayan,menurut data DKP Sikka Tahun 2015 jumlah nelayan di Kabupaten Sikka sebanyak 5085 orang yang dimana tergolong sebagai nelayan penuh sebanyak 1985 orang, nelayan sambilan utama sebanyak 892 orang, nelayan sambilan tambahan sebanyak 406 orang dan buruh nelayan sebanyak 1802.

Usaha perikanan purse seine merupakan usaha yang menjanjikan keuntungan cukup besar karena produktivitasnya yang tinggi (Ismy et al. 2014). Purse seine di Kabupaten Sikka merupakan alat tangkap yang dinilai penting karena alat tangkap purse seine lebih banyak menghasilkan ikan 
dibandingan dengan alat tangkap lainnya, berdasarkan data DKP Sikka (2015) jumlah hasil tangkapan purse seine dari tahun 2012 hingga tahun 2015 sebanyak 11.246 ton.

Kapal purse seine di Kabupaten Sikka pada umumnya memiliki ukuran 4-10 GT dengan jumlah personil mencapai 7-10 orang, setiap orang memiliki tugas yang berbeda-beda dan pada umumnya tugas masing-masing orang tersebut dilakukan secara manual sehingga sangat menguras tenaga dan pikiran. Karlos et al. (2014) menyatakan bahwa dalam melakukan aktivitas yang memerlukan tenaga dan pikiran akan sangat mempengaruhi tingkat kelelahan sehingga akan berdampak pada kecelakaan kerja, maka demikian untuk mengatasi permasalahan yang terjadi di atas perlu dilakukan analisis risiko pada aktivitas pengoperasian alat tangkap purse seine yang dimana rencana penelitian ini bertujuan untuk mengidentifikasi aktivitas dan melihat intensitas kerja nelayan purse seine yang dapat menimbulkan potensi kecelakaan pada saat melakukan pengoperasian alat tangkap purse seine.

\section{METODOLOGI}

Penelitian ini dilakukan pada bulan Juli hingga September tahun 2016. Lokasi penelitiandi kampung nelayan Wuring Kabupaten Sikka, Provinsi Nusa Tenggara Timur.

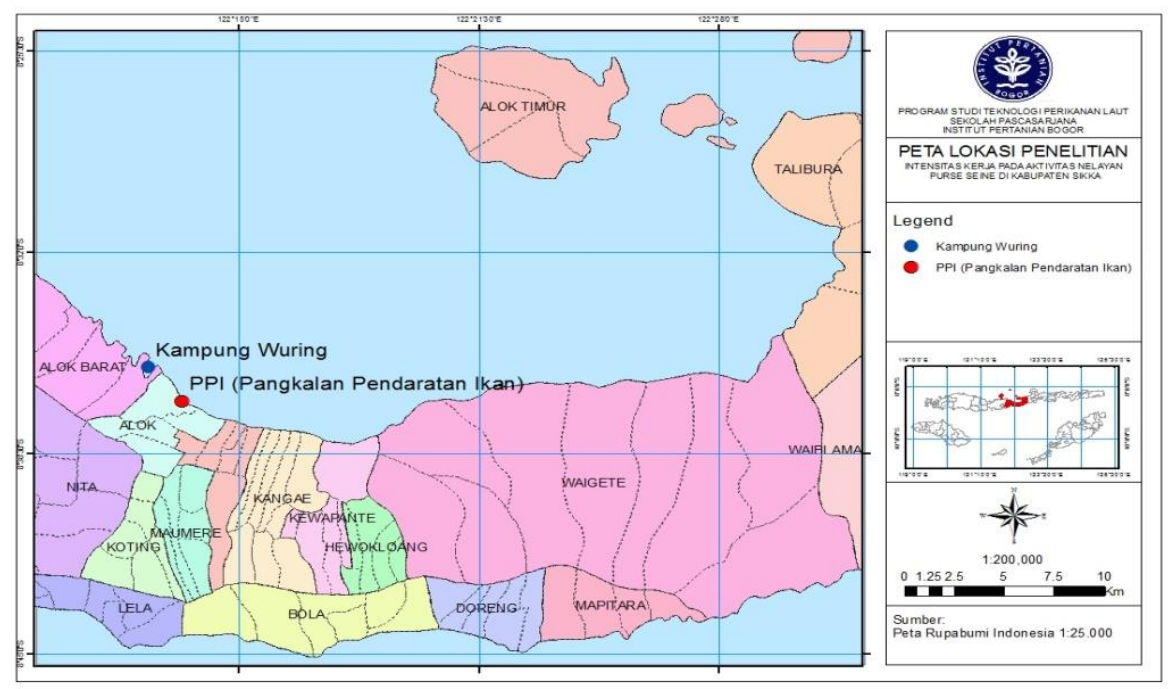

Gambar 2 Lokasi penelitian

Metode penelitian yang digunakan adalah metode observasi dan deskriptif kuantitatif. Metode observasi dilakukan secara langsung dengan mengikuti kegiatan pengoperasian alat tangkap purse seine yang dilakukan oleh nelayan Wuring Kabupaten Sikka mulai dari tahap persiapan hingga pembongkaran hasil tangkapan, sedangkan metode deskriptif kuantitatif yang digunakan pada rencana penelitian ini bertujuan untuk menggambarkan situasi dalam melakukan aktivitas pengoperasian alat tangkap purse seine yang berguna untuk menentukan nilai dari setiap tahapan dalam aktivitas tersebut.

Teknik pengumpulan data yang dilakukan dalam penelitian ini yaitu dengan pengambilan data primer dan sekunder. Pengumpulan data primer pada penelitian ini dilakukan melalui pengamatan dan wawancara langsung dengan semua pihak yang melakukan kegiatan pengoperasian alat tangkap purse seinedi atas kapal purse seine dengan ukuran 6 GT. Pengambilan data sekunder dengan cara melakukan pendekatan secara langsung dengan pihak instansi atau stakeholder yang berkaitan dengan bidang perikanan dan kelautan di Kabupaten Sikka. Prosedur teknik pengumpulan data untuk gambaran aktivitas nelayan purse seine di Kabupaten Sikka lebih mengacu kepada metode Formal Safety Assessment (FSA) dari IMO tahun 2002. 
Tabel 1 Jenis dan sumber data penelitian yang diperoleh.

\begin{tabular}{|c|c|c|}
\hline No & Jenis data & Sumber data \\
\hline \multirow[t]{4}{*}{1} & Unit penangkapan purse seine & \\
\hline & Kapal & Tonase, kondisi mesin, perlengkapan surat ijin \\
\hline & Alat tangkap purse seine & $\begin{array}{l}\text { Ukuran alat tangkap, kondisi alat tangkap, dan metode } \\
\text { pengoperasian }\end{array}$ \\
\hline & Nelayan & $\begin{array}{l}\text { Jumlah Nelayan (termasuk nakhoda dan ABK), umur, } \\
\text { pendidikan, struktur organisasi di atas kapal. }\end{array}$ \\
\hline \multirow[t]{11}{*}{2} & Tahap aktivitas purse seine & \\
\hline & & 1. Persiapan di darat \\
\hline & & 2. Loading \\
\hline & & 3. Berlayar ke Fishing Ground \\
\hline & & 4. Setting \\
\hline & & 5. Hauling \\
\hline & & 6. Penanganan hasil tangkapan di atas kapal \\
\hline & & 7. Berlayar ke pelabuhan pendaratan Ikan \\
\hline & & 8. Unloading hasil tangkapan \\
\hline & & 9. Berlayar menuju fishing base \\
\hline & & 10. Unloading dari atas kapal \\
\hline \multirow[t]{2}{*}{3} & Perlengkapan Alat Keselamatar & di Laut \\
\hline & & $\begin{array}{l}\text { Peralatan navigasi/emergency signal, fasilitas } \\
\text { pendukung keselamatan. }\end{array}$ \\
\hline \multirow[t]{2}{*}{4} & Data informasi kecelakaan kerj & a di laut \\
\hline & & $\begin{array}{l}\text { Dokumen-dokumen tentang kecelakaan yang pernah } \\
\text { terjadi di Kabupaten Sikka }\end{array}$ \\
\hline
\end{tabular}

\section{Aktivitas Pengoperasian Alat Tangkap Purse Seine di Kabupaten Sikka}

Analisis data yang digunakan dalam penelitian ini adalah Hierarchical Task Analysis (HTA). HTA merupakan suatu analisis yang digunakan untuk mengidentifikasi bahaya (identification of hazards) yang timbul pada setiap aktivitas yang dilakukan secara rinci dan bertahap. Lane et al. (2008) menyebutkan bahwa menganalisis proses pada tingkat kerja mampu membantu mengurangi error. Menurut Purwangka (2013) HTA juga dikenal sebagai planyang berfungsi untuk menjelaskan mengenai urutan dan kondisi suatu aktivitas yang dilakukan oleh manusia.Langkah pertama pada analisis HTA adalah mengidentifikasi aktivitas-aktivitas pada pengoperasian alat tangkap purse seine dengan menentukan jenis aktivitas yang dilakukan, selanjutnya menghitung jumlah aktivitas berdasarkan jenis aktivitas. Perhitungan jumlah aktivitas berdasarkan Handayani et al. (2014) yaitu jenis aktivitas dibagi menjadi dua aktivitas yang terdiri dari aktivitas primer dan aktivitas sekunder, sehingga dapat dirumuskan sebagai berikut.

Total aktivitas kerja $=\mathrm{f}$ (aktivitas perimer, aktivitas sekunder) sehingga dapat dijabarkan menjadi Total aktivitas kerja $=$

$\Sigma_{\mathfrak{i}=1} \wedge \mathrm{n}$ Primer $\mathfrak{i}+\Sigma_{\mathfrak{i}=1} \wedge \mathrm{n}$ Sekunder $\mathfrak{i}$.

Dimana

$\mathrm{i} \quad=$ Tahap ke $-1,2 \ldots \ldots, \mathrm{n}$

$\mathrm{n}=$ Jumlah tahap aktivitas 


\section{Intensitas Kerja Nelayan Purse Seine di Kabupaten Sikka}

Berkaitan dengan rencana penelitian yang akan dilakukan, aktivitas yang akan diidentifikasi adalah aktivitas keseluruhan baik dari tahap persiapan hingga pembongkaran hasil tangkapan sedangkan intensitas kerja (work intensity) diteliti melalui studi kuantitatif dengan menggunakan instrument survei sehingga dapat dipahami sebagai serangkaian pengukuran kecepatan kerja (pace of work) dan kebutuhan untuk memenuhi target dalam pencapaian waktu kerja. Intensitas kerja yang dimaksud adalah intensitas kerja primer dan sekunder dimana kedua intensitas kerja tersebut akandihitung untuk mendapatkan nilai total, Handayani et al. (2014). Agar dapat dipahami berikut dilampirkan rumus perhitungan kedua intensitas yang akan digunakan dalam penelitian ini.

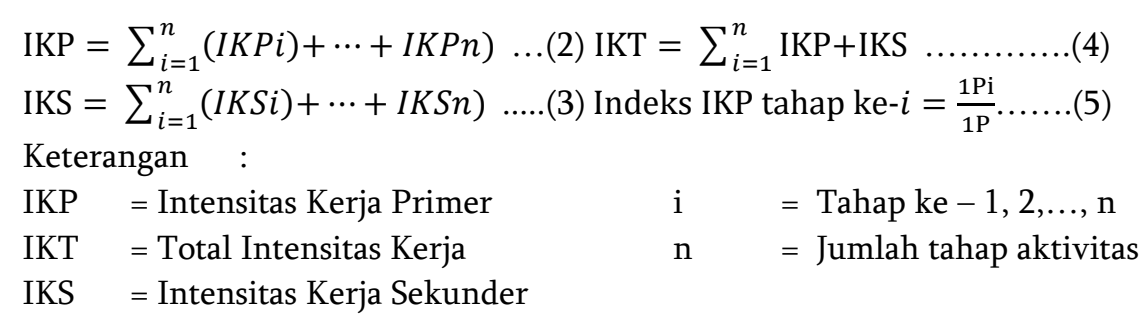

Berdasarkan perhitungan intensitas kerja diatas dapat dijelaskan bahwa nilai intansitas kerja primer (IKP) masing-masing tahapan aktivitas diurutkan dari nilai IKP terbesar hingga terkecil untuk menentukan nilai rengking setiap aktivitas sedangkan untuk menentukan intensitas kerja total (IKT) diperoleh dari perhitungan total IKP (2) dan IKS (3).

\section{HASIL DAN PEMBAHASAN}

Purse seine merupakan alat tangkap yang aktif karena dalam operasi penangkapan tersebut kapal melakukan pelingkaran jaring pada target penangkapan ikan. Menurut Brandt (1984) purse seine digolongkan ke dalam kelompok surrounding nets yang mana memiliki arti, alat penangkapan ikan berupa jaring yang berbentuk empat persegi panjang dan terdiri dari sayap, badan, dilengkapi pelampung, pemberat, tali ris atas, tali ris bawah dengan atau tanpa tali kerut/pengerut yang dimana salah satu bagiannya berfungsi sebagai kantong yang pengoperasiannya melingkari gerombolan ikan pelagis.

Alat tangkap purse seine merupakan salah satu alat tangkap yang banyak digunakan di Kabupaten Sikka. purse seine terbagi menjadi dua macam yaitu purse seine malam dan purse seine siang, berkaitan dengan penelitian yang dilakukan, purse seine yang digunakan adalah purse seine malam dengan ukuran panjang 200 meter, kedalaman 37 meter, dan ukuran mata jaring yang digunakan adalah 1/4 inci hingga 1 inci. Kapal penangkapan yang digunakan pada pengoperasian alat tangkap purseseinedi Kabupaten Sikka berkisar 4-10 GT dimana dengan jumlah awak kapal sebanyak 7-10 orang, sedangkan dalam penelitian ini kapal yang digunakan adalah kapal berukuran 6 GT dengan panjang (LOA) 19 meter dengan lebar 3.85 meter dan jumlah awak kapal yang bekerja dalam pengoperasian alat tangkap purse seine sebanyak 10 orang.

\section{Kondisi Umum Nelayan Perikanan Purse Seinedi Kabupaten Sikka.}

Nelayan purse seine di Kabupaten Sikka pada umumnya tidak dilatarbelakangi pendidikan khusus tentang kepelautan sehingga pada dasarnya nelayan di Kabupaten Sikka lebih mengandalkan pengalaman dan keterampilan mereka di bidang penangkapan ikan, dari data yang diperolehdi dinas kelautan dan perikanan tahun 2015, nelayan purse seine di Kabupaten Sikka pada umumnya terdiri dari perempuan 20\%, laki-laki 72\% dan anak-anak sebanyak $8 \%$ dengan rata-rata pendidikan terakhir nelayan tersebut terdiri dari SD 85\%, SMP 13\% dan SMA sebanyak 2\%. Menurut Suwardjo et al. (2010) untuk menjadi seorang nakhoda kapal wajib minimum berpendidikan menengah perikanan atau pendidikan SLTA (sekolah lanjutan tingkat atas) umum ditambah pelatihan kepelautan meliputi 
pelayaran dan pengoperasian kapal, keselamatan dan penangkapan ikan, sementara itu menurut PP Nomor 7 Tahun 2000 dikatakan bahwa setiap awak kapal (nakhoda dan ABK) kapal wajib memiliki pendidikan sertifikat kepelautan agar dapat memperoleh sertifikat keterampilan dasar keselamatan Basic Safety Training (BST).

\section{Status nelayan purse seine}

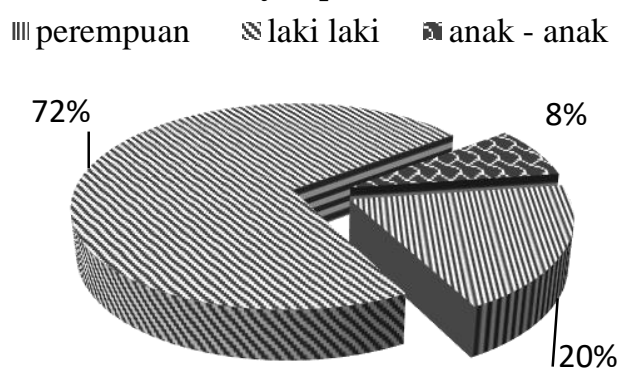

Pendidikan nelayan purse seine

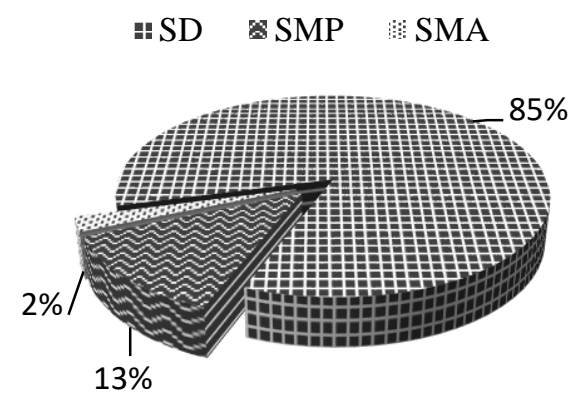

Sumber: Data sekunder laporan registrasi nelayan tahun dinas kelautan dan perikanan Kabupaten Sikka (2015)

Gambar 3 Status pendidikan nelayan purse seine di Kabupaten Sikka tahun 2015

Tujuan dari pendidikan pelatihan BST berfungsi untuk melatih peserta dalam konsep, prinsip dan teknik penyelamatan diri, pencegahan kebakaran dan pemadaman kebakaran, pertolongan pertama pada kecelakaan, keamanan diri dan tanggung jawab sosial di kapal (IMO 2010).

\section{Tahapan HTA (Hierarchical Task Analysis) Pengoperasian Alat Tangkap Purse Seine di Kabupaten Sikka}

Pengoperasian alat tangkap purse seine di Kabupaten Sikka dilakukan pada malam hingga pagi hari yang dimana tahapan tersebut selalu dilakukan oleh nelayan purse seine di Kabupaten Sikka. Pengoperasian alat tangkap purse seine di Kabupaten Sikka pada umumnya lebih mengandalkan tenaga dan pikiran yang dimana hal tersebut akan sangat mempengaruhi tingkat kelelahan hingga dapat mengakibatkan kecelakaan kerja.

Tahapan aktivitas nelayan purse seine di Kabupaten Sikka terdiri dari 10 tahapan aktivitas pokok dan sub aktivitas yang dimana setiap tahapan memiliki tingkat bahaya dan risiko yang tinggi. 10 tahapan pokok yang dilakukan oleh nelayan di Kabupaten Sikka terdiri dari: (1) Persiapan di darat, (2) Loading, (3) Berlayar ke fishing ground, (4) Setting, (5) Hauling, (6) Penanganan hasil tangkapan di atas kapal, (7) Berlayar ke pangkalan pendaratan ikan, (8) Unloading hasil tangkapan di PPI, (9) Berlayar menuju fishing base, (10) Unloading dari atas kapal, agar lebih jelas dan terperinci dapat dilihat dalam Tabel 2.

Tabel 2 Hierarchical Task Analysis (HTA) pengoperasian alat tangkap purse seine di Kabupaten Sikka.

\begin{tabular}{|c|c|c|c|c|}
\hline No & $\begin{array}{l}\text { Aktivitas } \\
\text { (plan) }\end{array}$ & $\begin{array}{c}\text { Penanggung } \\
\text { Jawab }\end{array}$ & $\begin{array}{c}\text { Intensitas Kerja } \\
(\mathrm{OA})=\text { Orang } \\
\text { Aktivitas }\end{array}$ & $\begin{array}{c}\text { Jenis } \\
\text { Aktivitas }\end{array}$ \\
\hline \multicolumn{5}{|c|}{ Tahap 1 (Persiapan di darat) } \\
\hline & $\begin{array}{l}\text { Pengurusan dokumen-dokumen SLO } \\
\text { dan SIB (setiap hari) }\end{array}$ & Pengurus/(Chief) & 1 & Primer \\
\hline & $\begin{array}{l}\text { Mendata ABK } \\
\text { 2.1 Pengecekan kehadiran ABK }\end{array}$ & Pengurus/(Chief) & 1 & Primer \\
\hline
\end{tabular}




\begin{tabular}{|c|c|c|c|c|}
\hline & 2.2 Pembagian tugas ABK & Pengurus/(Chief) & 1 & Primer \\
\hline \multicolumn{5}{|c|}{ 3. Pengecekan peralatan dan kebutuhan melaut } \\
\hline & 3.1 Pengecekan dan pengaturan mesin & Juru Mesin & 1 & Primer \\
\hline & 3.2 Pembelian BBM dan Oli samping & Juru Mesin & 2 & Sekunder \\
\hline & 3.3 Persiapan air minum & Kepala Kerja & 1 & Sekunder \\
\hline & $\begin{array}{l}\text { 3.4 Pengecekan dan perbaikan alat } \\
\text { tangkap }\end{array}$ & Kepala Kerja & 5 & Primer \\
\hline & 3.5 Persiapan box dan kantong plastik & Kepala Kerja & 3 & Primer \\
\hline \multicolumn{3}{|c|}{ Sub total tahap 1 : } & $15 \mathrm{OA}$ & \\
\hline \multicolumn{5}{|c|}{ Tahap 2 (loading) } \\
\hline 1. & Pengangkutan dan pengisian bensin & Kepala Kerja & 2 & Primer \\
\hline 2. & Pengangkutan jerigen air minum & Kepala Kerja & 3 & Sekunder \\
\hline 3. & Pengakutan box ke atas kapal & Kepala Kerja & 3 & Primer \\
\hline 4. & $\begin{array}{l}\text { Awak naik ke kapal dengan membawa } \\
\text { perbekalan masing-masing }\end{array}$ & Pengurus/(Chief) & 10 & Primer \\
\hline \multicolumn{3}{|c|}{ Sub total tahap 2: } & $18 \mathrm{OA}$ & \\
\hline \multicolumn{5}{|c|}{ Tahap 3 (Berlayar ke Fishing Ground) } \\
\hline \multicolumn{5}{|c|}{ 1. Bertolak dari dermaga } \\
\hline & 1.1 Melepas tali tambat & Nahkoda/Kapten & 1 & Primer \\
\hline & $\begin{array}{l}\text { 1.2 Nahkoda menyalakan mesin untuk } \\
\text { dipanaskan }\end{array}$ & Nahkoda/Kapten & 1 & Primer \\
\hline & $\begin{array}{l}\text { 1.3 Nahkoda mengarahkan kapal } \\
\text { keluar kolam pelabuhan }\end{array}$ & Nahkoda/Kapten & 1 & Primer \\
\hline \multirow[t]{4}{*}{2} & Persiapan alat tangkap & & & \\
\hline & $\begin{array}{l}2.1 \text { ABK membuka tali ris jaring yang } \\
\text { terikat }\end{array}$ & Kepala Kerja & 2 & Primer \\
\hline & $\begin{array}{l}2.2 \text { ABK memisahkan pelampung } \\
\text { jaring dan cincin }\end{array}$ & Kepala Kerja & 4 & Primer \\
\hline & $\begin{array}{l}2.3 \text { ABK memasukan tali penarik } \\
\text { pemberat ke roller }\end{array}$ & Kepala Kerja & 5 & Primer \\
\hline 3 & Awak kapal memakan pembekalan & Kepala Kerja & 10 & Sekunder \\
\hline 4 & ABK mematikan lampu di kapal & Kepala Kerja & 1 & Primer \\
\hline \multicolumn{3}{|c|}{ Sub Total Tahap 3 : } & $25 \mathrm{OA}$ & \\
\hline \multicolumn{5}{|c|}{ Tahap 4 (Setting) } \\
\hline 1 & $\begin{array}{l}\text { Nahkoda mengarahkan kapal } \\
\text { mendekati perahu lampu }\end{array}$ & Nahkoda/Kapten & 1 & Primer \\
\hline \multirow[t]{4}{*}{2} & Pemasangan alat tangkap & & & \\
\hline & 2.1 Menurunkan pelampung tanda & Kepala Kerja & 2 & Primer \\
\hline & $\begin{array}{l}\text { 2.2 Mengatur bagian jaring untuk } \\
\text { diturunkan }\end{array}$ & Kepala Kerja & 4 & Primer \\
\hline & $\begin{array}{l}\text { 2.3 Menurunkan bagian badan jaring } \\
\text { dan pemberat }\end{array}$ & Kepala Kerja & 8 & Primer \\
\hline 3 & $\begin{array}{l}\text { Nahkoda mengarahkan kapal } \\
\text { melingkari kawanan ikan }\end{array}$ & Nahkoda/Kapten & 1 & Primer \\
\hline \multirow[t]{2}{*}{4} & $\begin{array}{l}\text { ABK mempertahankan bentuk dan } \\
\text { posisi jaring }\end{array}$ & Kepala Kerja & 9 & Primer \\
\hline & Sub total tahap 4: & & $25 \mathrm{OA}$ & \\
\hline \multicolumn{5}{|c|}{ Tahap 5 (Hauling) } \\
\hline 1 & $\begin{array}{l}\text { Memberikan kode pada juru mesin } \\
\text { untuk menyalakan mesin roller }\end{array}$ & Kepala Kerja & 1 & Primer \\
\hline
\end{tabular}




\begin{tabular}{|c|c|c|c|c|}
\hline 2 & Juru mesin menyalakan mesin roller & Juru Mesin & 1 & Primer \\
\hline 3 & ABK memasang tali kolor ke roller & Kepala Kerja & 2 & Primer \\
\hline 4 & Juru mesin mengatur kecepatan roller & Juru Mesin & 1 & Primer \\
\hline 5 & $\begin{array}{l}\text { Mengatur posisi alat tangkap pada saat } \\
\text { hauling }\end{array}$ & Kepala Kerja & 1 & Primer \\
\hline 6 & ABK menyalakan lampu kapal & Kepala Kerja & 1 & Primer \\
\hline 7 & $\begin{array}{l}\text { ABK menarik dan mengangkat pemberat } \\
\text { serta badan jaring ke atas kapal }\end{array}$ & Kepala Kerja & 9 & Primer \\
\hline 8 & ABK menyusun cincin & Kepala Kerja & 4 & Primer \\
\hline 9 & $\begin{array}{l}\text { ABK mengatur alat tangkap agar mudah } \\
\text { disusun. }\end{array}$ & Kepala Kerja & 9 & Primer \\
\hline \multirow[t]{2}{*}{10} & $\begin{array}{l}\text { ABK melepaskan ikan yang tersangkut } \\
\text { pada badan jaring }\end{array}$ & Kepala Kerja & 9 & Primer \\
\hline & Sub total tahap 5 : & & $38 \mathrm{OA}$ & \\
\hline \multicolumn{5}{|c|}{ Tahap 6 (Penangan hasil tangkapan di atas kapal) } \\
\hline 1 & Penyortiran ikan hasil tangkapan & Kepala Kerja & 2 & Primer \\
\hline 2 & $\begin{array}{l}\text { Memindahkan ikan ke dalam box dan } \\
\text { kantong plastik apabila box sudah terisi } \\
\text { penuh }\end{array}$ & Kepala Kerja & 2 & Primer \\
\hline \multirow[t]{2}{*}{3} & $\begin{array}{l}\text { Merapikan bentuk jaring untuk } \\
\text { disimpan apabila tidak melakukan } \\
\text { setting lanjutan }\end{array}$ & Kepala Kerja & 8 & Primer \\
\hline & Sub total tahap 5 : & & $12 \mathrm{OA}$ & \\
\hline \multicolumn{5}{|c|}{ Tahap 7 (Berlayar ke Pangkalan pendaratan ikan) } \\
\hline 1 & Nahkoda mengarahkan arah menuju PPI & Nahkoda/Kapten & 1 & Primer \\
\hline 2 & $\begin{array}{l}\text { Nahkoda mengatur kecepatan mesin } \\
\text { kapal }\end{array}$ & Nahkoda/Kapten & 1 & Primer \\
\hline 3 & $\begin{array}{l}\text { ABK mengatur dan merapikan alat } \\
\text { tangkap }\end{array}$ & Kepala Kerja & 8 & Primer \\
\hline 4 & ABK membersihkan lantai dek kapal & Kepala Kerja & 2 & Primer \\
\hline 5 & $\begin{array}{l}\text { ABK memakan pembekalan dan } \\
\text { beristirahat. }\end{array}$ & Kepala Kerja & 8 & Sekunder \\
\hline
\end{tabular}

\begin{tabular}{|c|c|c|c|c|}
\hline \multicolumn{3}{|c|}{ Sub Total Tahap 7 : } & \multicolumn{2}{|l|}{$20 \mathrm{OA}$} \\
\hline \multicolumn{5}{|c|}{ Tahap 8 (Unloading hasil tangkapan) } \\
\hline 1 & $\begin{array}{l}\text { Melempar tali dan menurunkan } \\
\text { jangkar }\end{array}$ & Kepala Kerja & 2 & Primer \\
\hline 2 & Nahkoda mematikan mesin & Nahkoda/Kapten & 1 & Primer \\
\hline 3 & $\begin{array}{l}\text { ABK mengumpulkan dan } \\
\text { membersihkan ikan yang diperoleh }\end{array}$ & Nahkoda/Kapten & 7 & Primer \\
\hline 4 & $\begin{array}{l}\text { ABK melakukan tawar menawar } \\
\text { dengan pembeli di atas kapal }\end{array}$ & Kepala Kerja & 5 & Primer \\
\hline 5 & $\begin{array}{l}\text { ABK menurunkan hasil tangkapan dan } \\
\text { membawa ke pangkalan menggunakan } \\
\text { perahu kecil }\end{array}$ & Kepala Kerja & 3 & Primer \\
\hline 6 & $\begin{array}{l}\text { ABK memberikan ikan hasil tangkapan } \\
\text { kepada Tangkulak/Papalele }\end{array}$ & Nahkoda/Kapten & 3 & Primer \\
\hline 7 & $\begin{array}{l}\text { ABK membeli makanan dan minuman } \\
\text { di pelabuhan }\end{array}$ & Pengurus/(Chief) & 2 & Sekunder \\
\hline
\end{tabular}




\begin{tabular}{|c|c|c|c|c|}
\hline 8 & ABK memakan makanan yang di beli & Kepala Kerja & 8 & Primer \\
\hline 9 & ABK beristirahat sambil berbaring & Kepala Kerja & 5 & Sekunder \\
\hline \multicolumn{3}{|c|}{ Sub total tahap 8: } & \multicolumn{2}{|l|}{$36 \mathrm{OA}$} \\
\hline \multicolumn{5}{|c|}{ Tahap 9 (Berlayar menuju fishing base) } \\
\hline 1 & ABK menarik dan menaikan jangkar & Kepala Kerja & 2 & Primer \\
\hline 2 & $\begin{array}{l}\text { Nahkoda menghidupkan mesin dan } \\
\text { mengarahkan kapal keluar dari } \\
\text { pangkalan }\end{array}$ & Nahkoda/Kapten & 1 & Primer \\
\hline 3 & $\begin{array}{l}\text { ABK mengatur dan membersihkan dek } \\
\text { kapal }\end{array}$ & Kepala Kerja & 4 & Primer \\
\hline 4 & Nahkoda menurunkan kecepatan kapal & Nahkoda/Kapten & 1 & Primer \\
\hline 5 & $\begin{array}{l}\text { ABK mengangkat tali tambat dan } \\
\text { mengaitkannya pada kapal }\end{array}$ & Kepala Kerja & 1 & Primer \\
\hline \multicolumn{3}{|c|}{ Sub total tahap 9: } & $90 A$ & \\
\hline \multicolumn{5}{|c|}{ Tahap 10 (Unloading dari atas kapal) } \\
\hline 1 & ABK memasang tali tambat & Kepala Kerja & 1 & Primer \\
\hline 2 & $\begin{array}{l}\text { ABK mengeluarkan air pada lambung } \\
\text { kapal }\end{array}$ & Kepala Kerja & 1 & Primer \\
\hline 3 & ABK melepaskan tali perahu & Kepala Kerja & 1 & Primer \\
\hline 4 & $\begin{array}{l}\text { Awak kapal turun dari kapal } \\
\text { menggunakan perahu }\end{array}$ & Kepala Kerja & 10 & Primer \\
\hline
\end{tabular}

Sub total tahap 10 :

$13 \mathrm{OA}$

Porsi Tanggung Jawab Kerja Awak Kapal Pada Pengoperasian Alat Tangkap Purse Seine di Kabupaten Sikka

Aktivitas pengoperasian alat tangkap purse seine di Kabupaten Sikka menunjukan bahwa porsi kerja yang paling banyak adalah kepala kerja dengan presentasi sebesar 81\%, sedangkan porsi kerja nahkoda/kapten $10 \%$, pengurus/chief $7 \%$ dan juru mesin hanya memperoleh presentasi sebesar $2 \%$.

Kepala kerja diatas kapal purse seine 6 GTdi Kabupaten Sikka merupakan salah seorang yang ditunjuk oleh pemilik kapal untuk mengatur segala sesuatu yang dilakukan di atas kapal. Hal ini bertujuan untuk tidak membebani awak kapal lain, disisi lain tujuan dipilihnya kepala kerja adalah untuk sebagai pemandu kegiatan yang terjadi dalam melakukan aktivitas penangkapan ikan dengan alat tangkap purse seine. Kepala kerja diatas kapal biasanya ditunjuk oleh juragan/ pemilik kapal dan kebanyakan yang menjadi kepala kerja merupakan anak atau keluarga dari juragan/pemilik kapal itu sendiri.

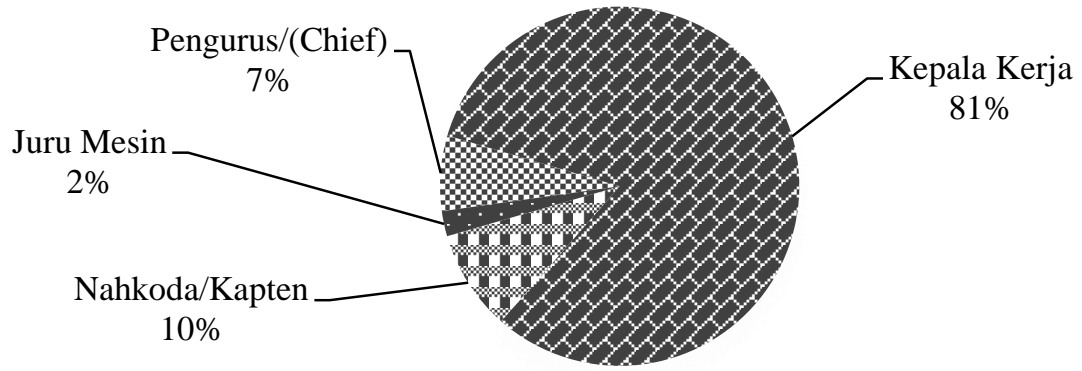

Gambar 4 Porsi kerja awak kapal purse seine 6 GT Kabupaten Sikka 2016 


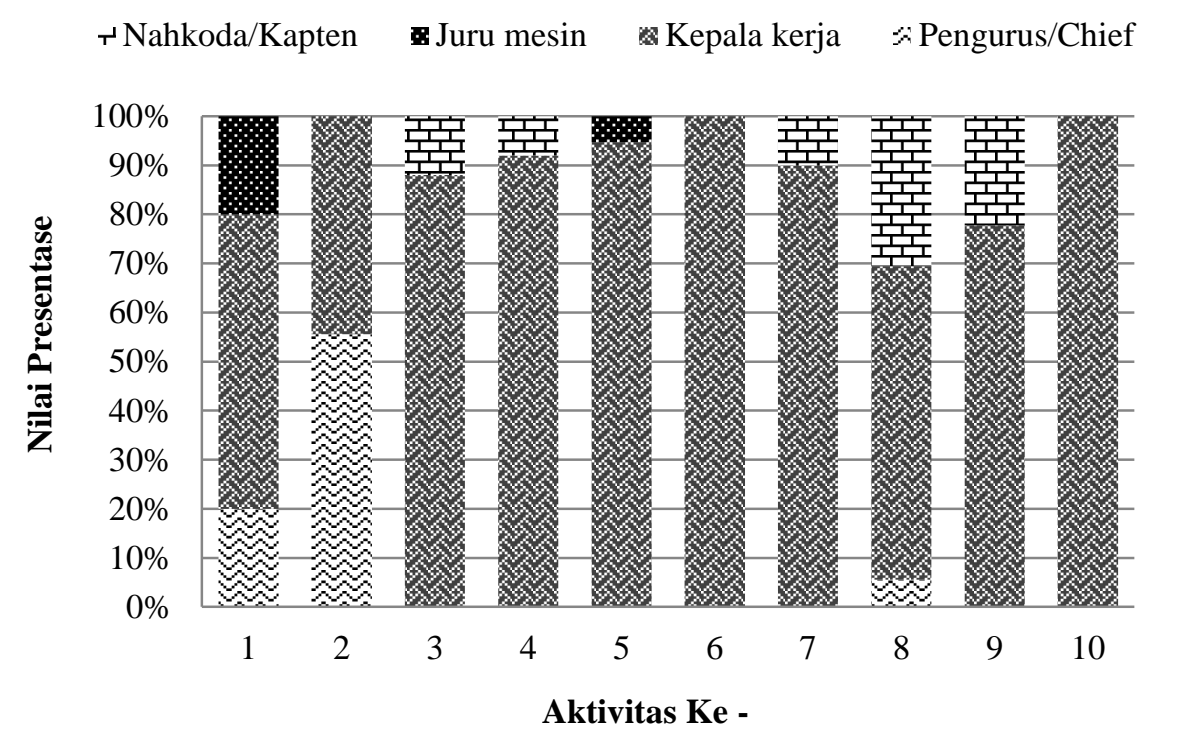

Gambar 5 Porsi kerja per tahap aktivitas awak kapal purse seine 6 GT Kabupaten Sikka 2016

Gambar 5 menunjukan porsi kerja setiap tahapan aktivitas awak kapal purse seine saat melakukan kegiataan penangkapan ikan. Pada setiap tahap aktivitas dapat dilihat bahwa kepala kerja memiliki porsi tanggung jawab kerja paling tinggi,tahap aktivitas ke 1 porsi tanggung jawab kepala kerja mencapai 60\%, sedangkan nahkoda/kapten 0\%, juru mesin 20\%, dan pengurus/chief $20 \%$ di tahap aktivitas ke 2 porsi tanggung jawab kepala kerja sebesar 44\%, pengurus/chief $56 \%$, nahkoda/kapten dan juru mesin $0 \%$. Tahap aktivitas ke 3 porsi tanggung jawab kepala kerja $88 \%$, nahkoda/kapten $12 \%$, juru mesin dan penguruschief $0 \%$, untuk tahapan selanjutnya tahapaktivitas ke 4 porsi tanggung jawabkepala kerja sebesar $92 \%$, nahkoda/kapten $8 \%$, juru mesin dan penguruschief $0 \%$. Tahapan dalam aktivitas ke 5 porsi tanggung jawab kepala kerja sebesar 95\%, juru mesin 5\%, nahkoda/kapten dan pengurus/chief 0\%, tahap aktivitas ke 6 kepala kerja memiliki porsi tanggung jawab sebesar $100 \%$ sedangkan nahkoda/kapten, pengurus/chief dan juru mesin memiliki porsi kerja $0 \%$. Tahap aktivitas ke 7 porsi tanggung jawab kepala kerja sebesar 90\%, nahkoda/kapten 10\%, pengurus/chief dan juru mesin $0 \%$, di tahap aktivitas 8 porsi tanggung jawab kepala kerja sebanyak 64\%, nahkoda/kapten 31\%, pengurus/chief 5\% dan juru mesin 0\%. Porsi tanggung jawab tahap 9 kepala kerja sebanyak 89\%, nahkoda/kapten $11 \%$ sedangkan pengurus/chief dan juru mesin $0 \%$, di tahap ke 10 kepala kerja memiliki tanggung jawab sebesar 100\% sedangkan pengurus/chief, nahkoda/kapten dan juru mesin $0 \%$.

\section{Intensitas Kerja Nelayan Pada Pengoperasian Alat Tangkap Purse Seine di Kabupaten Sikka}

Intensitas kerja nelayan merupakan besarnya usaha suatu individu dalam melakukan sesuatu kegiatan atau pekerjaan sebagai nelayan. pada penelitian ini untuk menghitung intensitas kerja dilihat dari setiap aktivitas masing-masing awak yang bekerja di atas kapal purse seine berkapasitas 6 GT, rincian aktivitas tersebut terdiri dari dua aktivitas yaitu aktivitas primer dan sekunder. Agar lebih jelasnya dapat dilihat pada tabel 3.

Pada daftar tabel 3 di atas dapat dijelaskan bahwa, pengoperasian alat tangkap purse seine di atas kapal 6 GT memiliki 10 tahapan dengan 62 jumlah total aktivitas yang terdiri dari 55 aktivitas primer dan 7 aktivitas sekunder. Aktivitas primer merupakan aktivitas yang harus atau wajib dilakukan pada urutan tahapan dalam sebuah kegiatan hal tersebut dikarenakan aktivitas primer akan sangat mempengaruhi keberhasilan dalam proses untuk mencapai sebuah tujuan yang dikehendaki sedangkan aktivitas sekunder merupakan suatu aktivitas yang tidak harus dilakukan sesuai urutannya karena aktivitas sekunder merupakan aktivitas pendukung dalam suatu pencapaian atau kata lain aktivitas sekunder dapat dilakukan apabila aktivitas primer sudah terpenuhi atau sudah dilakukan. 
Tabel 3 Jumlah aktivitas primer dan sekunder pada pengoperasian alat tangkap purse seine.

\begin{tabular}{cccc}
\hline Tahap Ke - & \multicolumn{2}{c}{$\sum$ Aktivitas } & Total Aktivitas \\
\hline & Primer & Sekunder & \\
1 & 6 & 2 & 8 \\
2 & 3 & 1 & 4 \\
3 & 7 & 1 & 8 \\
4 & 6 & 0 & 6 \\
5 & 10 & 0 & 10 \\
6 & 3 & 0 & 3 \\
7 & 4 & 1 & 5 \\
8 & 7 & 2 & 9 \\
9 & 5 & 0 & 5 \\
10 & 4 & 0 & 4 \\
\hline Total & 55 & $\mathbf{7}$ & 62 \\
\hline
\end{tabular}

$11 \%$

Primer : Sekunder

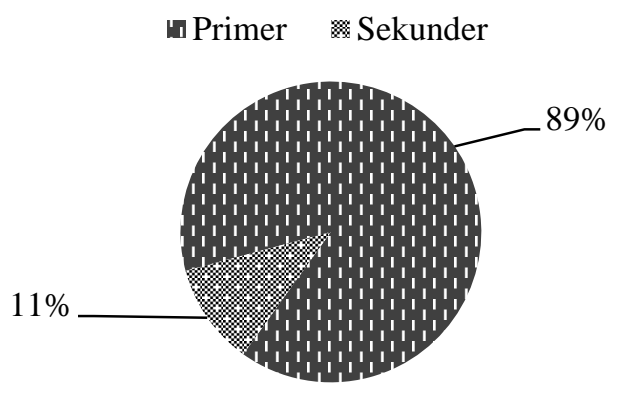

Gambar 5. Presentase aktivitas primer dan sekunder pada pengoperasian alat tangkap purse seine di atas kapal $6 \mathrm{GT}$

Tabel 4 Intensitas kerja awak kapal purse seine

\begin{tabular}{cccccc}
\hline $\begin{array}{c}\text { Tahap ke- } \\
\text { (i) }\end{array}$ & $\begin{array}{c}\text { IKPi } \\
(\mathrm{OA})\end{array}$ & $\begin{array}{c}\text { IKSi } \\
(\mathrm{OA})\end{array}$ & $\begin{array}{c}\text { IKTi } \\
(\mathrm{OA})\end{array}$ & Indeks IKPi & Ranking \\
\hline & & & & & \\
1 & 12 & 3 & 15 & 0.067 & 7 \\
2 & 15 & 3 & 18 & 0.083 & 5 \\
3 & 15 & 10 & 25 & 0.083 & 4 \\
4 & 25 & 0 & 25 & 0.139 & 3 \\
5 & 38 & 0 & 38 & 0.211 & 1 \\
6 & 12 & 0 & 12 & 0.063 & 9 \\
7 & 12 & 8 & 20 & 0.063 & 8 \\
8 & 29 & 7 & 29 & 0.152 & 2 \\
9 & 9 & 0 & 9 & 0.050 & 10 \\
10 & 13 & 0 & 13 & 0.072 & 6 \\
\hline TOTAL & 180 & 31 & $\mathbf{2 1 1}$ & & \\
\hline
\end{tabular}


Hasil perhitungan intensitas kerja yang diperoleh menunjukan bahwa terdapat 3 rangking aktivitas tertinggi yang terdiri dari tahapan ke-5, 8, dan 4 (hauling, unloading hasil tangkapan dan setting) dengan nilai indeks sebesar $0.211,0.152,0.131$ dan total intensitas kerja primer sebanyak 38 , 29, 25 OA. Total intensitas kerja primer (IKP) pada pengoperasian alat tangkap purse seine sebanyak 180 OA sedangkan total intensitas kerja sekunder (IKS) sebanyak $31 \mathrm{OA}$, dan untuk intensitas kerja total (IKT) pada pengoperasian alat tangkap purse seine adalah $211 \mathrm{OA}$. Hasil perhitungan intensitas kerja di atas dapat diartikan bahwa untuk melakukan pengoperasian alat tangkap purse seine dengan menggunakan kapal berkapasitas 6 GT membutuhkan usaha atau keterlibatan awak kapal setara dengan 211 orang dan pada hasil perhitungan intensitas kerja dapat dijelaskan bahwa pengoperasian alat tangkap purse seine dengan kapal 6 GT terdapat 3 tahap yang memiliki risiko tinggi, oleh karena itu perlu adanya perhatian dan pembenahan mengenai 3 tahapan aktivitas tersebut sehingga kedepannya tidak timbul risiko yang berdampak pada kecelakaan saat melakukan pengoperasian alat tangkap purse seine di Kabupaten Sikka.

Menurut FAO (2009) penyebab utama kecelakaan dan hilangnya nyawa manusia tidak hanya dari buruknya rancangan, pembuatan, dan perlengkapan kapal, namun juga perilaku manusia yang tidak pantas terkadang diperparah oleh kesalahan, keteledoran atau ketidaktahuan manusia itu sendiri. Pada hasil penelitian menunjukan bahwa tahap hauling merupakan tahapan aktivitas yang memiliki risiko paling tinggi dengan nilai indeks sebesar 0.211\%, menurut Josephus (2011) kegiatan pengoperasian alat tangkap purse seine merupakan suatu kegiatan yang sangat mengandalkan kekuatan fisik manusia dimana pada saat melakukan kegiatan hauling setiap awak kapal wajib menarik cincin dan jaring secara bersamaan dan hal ini harus dilakukan secara cepat agar ikan tidak mudah keluar dari kantong jaring namun hal tersebut akan berdampak pada tingkat kelelahan yang berujung pada kecelakaan kerja.

Kelelahan pada saat bekerja sangat mempengaruhi waktu kerja dan kinerja kerja sehingga dapat menciptakan kesalahan dalam bekerja yang dapat mengakibatkan risiko pada pengoperasian alat tangkap purse seine, pernyataan tersebut sama halnya seperti yang dikemukakan oleh Nurmianto (2013), yaitu semua jenis pekerjaan yang melebihi kapasitas kerja seseorang akan berdampak pada tingkat kelelahan, dimana kelelahan kerja akan mempengaruhi kinerja kerjayang dapat menimbulkan kesalahan dalam kerja sehingga akan berpeluang terjadinya kecelakaan kerja.

\section{KESIMPULAN DAN SARAN}

\section{Kesimpulan}

Hasil penelitian yang dilakukan di Kabupaten Sikka dapat disimpulkan bahwa intensitas kerja yang paling tinggi terdapat pada tahap hauling, unloading hasil tangkapan dan setting dimana pada tahap tersebut menunjukkan level aktivitas paling tinggi dengan Indeks Intensitas kerja sebesar 0.211, $0.152,0.131$.

\section{Saran}

Perlu adanya penambahan alat bantu kerja pada setiap tahapan aktivitas yang dianggap membahayakan sehingga intensitas kerja nelayan dapat berkurang dan akan memberikan ketenangan serta keselamatan kerja bagi nelayan.

\section{DAFTAR PUSTAKA}

[BASARNAS] Badan Search And Rescue Nasional. 2016. Data Kecelakaan Pelayaran Wilayah Kabupaten Sikka Provinsi Nusa Tenggara Timur. Kupang (ID): BASARNAS.

Brandt AV. 1984. Fish Catching Methods of the World. London (GB): Fishing News Books Ltd. 
[DKP] Dinas Kelautan dan Perikanan. 2015. Data Jumlah Alat Tangkap dan Armada Penangkapan Ikan di Kabupaten Sikka, Provinsi Nusa Tenggara Timur. Sikka (ID): DKP.

[FAO] Food Agriculture Organization. 2009. The State of World Fisheries and Aquaculture 2008. Rome (IT): FAO. 176 p.

Handayani SN. 2014. Sistem keselamatan kerja nelayan pada perikanan soma pajeko (mini purse seine) di Bitung. [tesis]. Bogor (ID). Institut Pertanian Bogor.

Handayani SN, Wisudo SH, Iskandar BH, Haluan J. 2014. Intensitas kerja aktivitas nelayan pada pengoperasian soma pajeko (mini purse seine) di Bitung. JTPK. 5(1):1-13.

Ismy F, Utomo B, Harahap ZA. 2014. Kajian unit penangkapan purse seine di Pelabuhan Perikanan Samudera Belawan. Jurnal Aquacoastmarine. 4(3):61-68.

[IMO] International Maritime Organization. 2002. Guidelines for FSA (Formal Safety Assessment) for Use in the IMO Rule-Making Process. London (GB): IMO.

[IMO] International Maritime Organization. 2010. Adoption of the Final Act and Any Instruments, Resolutions Andrecommendations Resulting From the Work of the Conference. London (GB): IMO.

Josephus J. (2011). Intervensi ergonomi pada proses penangkapan ikan dengan pukat cincin meningkatkan kinerja dan kesejahteraan nelayan di amurang kabupaten minahasa selatan provinsi sulawesi utara. [disertasi]. Bali (ID): Universitas Udayana. $256 \mathrm{hlm}$.

Karlos C, Josephus J, Kawatu P. 2014. Hubungan Antara Aktivitas Fisik Dengan Kelelahan Kerja pada Tenaga Kerja Bongkar Muat (Tkbm) di Pelabuhan Manado.1-6 hlm. [internet]. [diunduh 2016 September 19]: Tersedia pada: http://fkm.unsrat.ac.id/wp-content/uploads/2014/08/.pdf.

Lane R, Stanton, NA, Harrison D. 2008. Hierarchical task analysis to medication administration errors. Appl Ergon. 37(5): 669-679. doi: 10.1016/j.apergo.2005.08.001.

Lincoln JM, Husberg BJ, Conway GA. 2002. Improving Safety in the Alaskan Commercial Fishing Industry. Di dalam: Lincoln JM, Hudson DS, Conway GA, Pescatore R, Editor. Proceedings of the International Fishing Industry Safety and Health Conference; 2000 Oct 23-25; Massachusetts, U.S.A. Massachusetts (US): National Institute for Occupational Safety and Health. 211-221 hlm.

Nurmianto E. 2003. Ergonomic Konsep Dasar dan Aplikasinya. Surabaya (ID). Institut Teknologi Sepuluh November.

[PP] Peraturan Pemerintah. 2002. Peraturan Pemerintah Republik Indonesia Nomor 7 Tahun 2000 tentang Kepelautan. Jakarta (ID): Departemen Perhubungan.

Purwangka F. 2013. Keselamatan kerja nelayan pada operasi penangkapan ikan menggunakan payang di Palabuhanratu, Jawa Barat [disertasi]. Bogor (ID): Institut Pertanian Bogor.

Suwardjo D, Haluan J, Jaya I, Poernomo SH. (2010). Kajian tingkat kecelakaan fatal, pencegahan dan mitigasi kecelakaan kapal-kapal penangkap ikan yang berbasis operasi di PPP Teglsari, PPN Pekalongan dan PPS Cilacap. JTPK. 10(1):61-72.

Thimotius J. 2015. Aspek keselamatan kerja kapal purse seine di tempat pelelangan ikan Pelabuhan Kota Tegal. Universitas Pancasakti Tegal. Oceatek 9(1):103-112.

Wibisono B. 2013. Faktor-faktor yang berhubungan dengan kejadian kecelakaan kerja pada pekerja tambang pasir gali di Desa Pegiringan Kabupaten Pemalang [skripsi]. Semarang (ID). Universitas Dian Nuswantoro. 